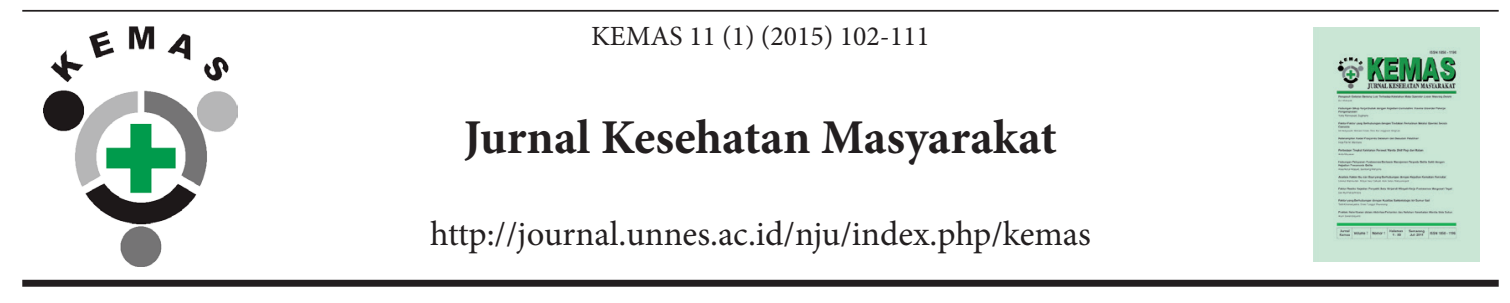

\title{
KHASIAT JAMU CEKOK TERHADAP PENINGKATAN BERAT BADAN PADA ANAK
}

\author{
Marni ${ }^{\bowtie}$, Retno Ambarwati \\ Akper Giri Satria Husada Wonogiri
}

\section{Info Artikel}

\section{Sejarah Artikel:}

Diterima 22 April 2015

Disetujui 30 Juni 2015

Dipublikasikan Juli 2015

Keywords:

Cekok Herbal

Medicine; Weight; Children

DOI

http://dx.doi.org/10.15294/

kemas.v11i1.3522

\begin{abstract}
Abstrak
Anak usia di bawah lima tahun sering mengalami penurunan nafsu makan, yang mengakibatkan berkurangnya asupan nutrisi sehingga berat badan menurun. Penelitian ini bertujuan untuk mengetahui khasiat ramuan jamu cekok terhadap peningkatan berat badan pada anak. Metode penelitian : penelitian kualitatif, pengumpulan data dilakukan pada keluarga yang memberikan jamu cekok pada anak balitanya, dukun bayi/pembuat jamu, herbalis dan petugas kesehatan. Penelitian dilakukan pada bulan Maret-Juni 2014, di wilayah Puskesmas Selogiri dengan pendekatan kualitatif, Seluruh rangkaian dan cara kerja ataupun proses penelitian kualitatif ini berlangsung secara serentak dilakukan dengan pengumpulan, pengolahan, menginterpretasikan sejumlah data dan fakta yang ada selanjutnya disimpulkan dengan metode induktif. Hasil penelitian : ramuan jamu cekok berkhasiat meningkatkan berat badan adalah: temu ireng ( curcuma aeroginosa), temulawak (curcuma xanthorriza robx), kencur (kaempferla galanga L), Meniran (Phyllanthus niruri), lempuyang emprit (zingiber americans), daun pepaya (carica papaya 1), kunyit (curcuma domestica val), sambiloto dan tempe busuk.
\end{abstract}

\section{THE FUNCTION OF CEKOK HERBAL MEDICINE IN THE INCREASING OF CHILDREN WEIGHT}

\begin{abstract}
Toodler get a decreasing of their appetite, that causes the reducing of nutrition so their weght reduce. This research purposes to know the function of cekok herbal and the benefits to weight gain in children. Research Method: qualitative research, Colleting data is got from the family that give the herbal medicine of cekok in toddler, herbal medicine maker, herbalist and paramedics. The study was conducted in March and June 2014 in the PHC Selogiri area by using qualitative approach. All of sequance or processing of qualitative research took place simultaneously. The result: The ingredients Cekok has function to promote the weight, there are : Curcuma aeroginosa, Curcuma xanthorriza robx, kaempferla galanga L, Meniran Phyllanthus niruri, Zingiber americans, Carica papaya l, (curcuma domestica val), bitter and rotten tempeh.
\end{abstract}

(C) 2015 Universitas Negeri Semarang 


\section{Pendahuluan}

Anak usia di bawah lima tahun sering mengalami penurunan nafsu makan, yang mengakibatkan berkurangnya asupan nutrisi sehingga berat badan menurun atau kurang dari usianya. Nafsu makan yang menurun seringkali dikaitkan dengan faktor internal seperti terjangkitnya anak dengan infeksi cacing. Sedangkan faktor eksternal yang menyebabkan penurunan nafsu makan pada anak seperti bentuk yang tidak menarik, kesalahan orangtua dalam menyajikan variasi makanan, atau karena anak sudah mulai aktif dengan bermain seperti anak usia Todler (1 - 3 tahun). Anak usia todler mempunyai ciri khas bergerak aktif, tidak bisa diam, dan sulit duduk dalam waktu lama, sehingga membutuhkan energi lebih banyak. Selain itu, pada usia 12 bulan sampai 18 bulan pertumbuhannya lambat sehingga kebutuhan nutrisi dan kalori menurun. Sedangkan penyebab umum menurunnya nafsu makan pada anak usia pra sekolah karena anak lebih tertarik bermain dengan teman atau lingkungannya daripada makan. Hal ini bisa menyebabkan anak menderita kurang gizi. Kondisi seperti ini jika dibiarkan akan menyebabkan terjadinya gangguan nutrisi pada anak, yang sering disebut anak dengan gizi buruk atau KKP (kurang kalori protein). Menurut Zulaekah (2014), menyatakan bahwa malnutrisi dalam bentuk anemia defisiensi besi memberikan dampak yang luas termasuk menurunkan kapasitas kerja, menurunkan regulasi panas, disfungsi imunitas, gangguan saluran cerna dan menurunkan kemampuan kognitif.

Status gizi anak memiliki peranan penting dalam mendukung pencapaian Millenium Development Goals (MDG's) di Indonesia khususnya sebagai indikator tingkat kematian balita (Setyowati, 2015). Menurut Rahim (2014), menyatakan bahwa prevalensi status gizi balita yang tergolong berat badan kurang (underweight) adalah 17,9\%. Sedangkan menurut data dinas kesehatan RI tercatat 4\% / 900 ribu balita yang tersebar di seluruh Indonesia menyandang status gizi buruk, hal ini menempatkan Indonesia menduduki peringkat 5 besar pemilik gizi buruk balita di dunia (Dewi, 2012).

Nafsu makan sering dikaitkan dengan status kesehatan seseorang. Kurang nafsu makan bukanlah suatu penyakit, melainkan salah satu gejala dari beberapa penyakit. Pada anak balita kurang nafsu makan, atau sama sekali tidak ada, dalam istilah kedokteran disebut anorexia. Kondisi ini akan menyebabkan anak menjadi kurus.

Anorexia pada anak bisa diatasi dengan ramuan jamu yang secara umum meningkatkan metabolisme tubuh anak. Ramuan tersebut juga bermanfaat untuk menekan dan menghambat asam lambung, merangsang sekresi makanan, merangsang enzimatis sehingga perut terasa kosong dan akan mengirim sinyal ke otak yang akan menimbulkan rasa lapar sehingga muncul keinginan untuk makan. Dalam upaya mengatasi anak yang sulit makan, para orang tua biasanya berupaya dengan berbagai cara supaya anaknya mau makan. Tindakan yang dilakukan orang tua pada umumnya adalah memberi anak vitamin penambah nafsu makan dan konsultasi dengan petugas kesehatan. Dinas kesehatan terkait khususnya puskesmas dan posyandu sudah berusaha mendata dan memberikan tindakan pada anak yang status gizinya masih dibawah garis kuning, yaitu dengan PMT (pemberian makanan tambahan), vitamin $\mathrm{A}$, pendidikan kesehatan tentang manfaat nutrisi, dan lain sebagainya. Walaupun sudah ada tindakan dari pemerintah untuk mengatasi kurang gizi, namun masih banyak anak yang berat badannya di garis kuning, bahkan dibawah garis merah. Perlu pendampingan keluarga untuk meningkatkan kesehatan anak balita. Penelitian yang telah dilakukan oleh Suryanto (2014), menyatakan bahwa pendampingan keluarga mampu meningkatkan pengetahuan keluarga terkait penyediaan nutrisi yang adekuat bagi anak. Pola asuh pemberian makan anak dan tingkat konsumsi energi dan protein berhubungan dengan underweight pada balita umur 7-59 bulan. Untuk itu keluarga harus mengetahui makanan apa saja yang bergizi dan dibutuhkan oleh balita, sehingga orang tua diharapkan menyediakan makanan tersebut untuk memenuhi kebutuhan balita.

Selain upaya yang sudah dilakukan tersebut, sebetulnya ada cara yang mudah dan murah untuk bisa meningkatkan nafsu makan pada anak, yaitu dengan pemberian jamu cekok. 
Penyakit gastrointestinal yang dikenal sebagai tidak nafsu makan dapat diatasi dengan jamu cekok. Selain itu jamu cekok juga dipercaya mengatasi batuk pilek pada anak (Limananti, 2003).

Dari hasil wawancara pendahuluan dengan lima orang ibu yang memiliki anak balita dengan status berat badan di bawah garis merah didapatkan data bahwa anak sering mengalami kurang nafsu makan, batuk, pilek, perut kembung, diare dan lain sebagainya, yang menyebabkan anak menjadi kurang sehat, dan tidak bisa beraktivitas dengan maksimal. Beberapa orang tua yang mempunyai balita memberikan jamu cekok dengan cara membeli / pesan kepada tukang jamu, dukun atau ada yang dibuat sendiri. Penjual jamu keliling yang membuat jamu cekok pesanan biasanya membuat jamu dengan cara semua bahan jamu ditumbuk sampai halus, kemudian dikukus sampai matang menggunakan daun pisang sebagai pembungkusnya.

Orang tua yang memberikan jamu cekok untuk anaknya tersebut mengatakan nafsu anak meningkat, sehingga frekuensi makan dan jumlah yang dimakan menjadi lebih banyak sehingga berat badan anak juga mengalami peningkatan. Ada juga yang mengatakan bahwa jamu cekok bisa menyembuhkan masuk angin, diare dan cacingan. Untuk mengatasi diare pada anak tanaman obat yang dipakai adalah kunyit empu 1 ibu jari diparut, kemudian diambil airnya dan ditambahkan madu, kemudian diberikan kepada anak dengan cara dicekok (dipaksa / dicangar). Di era yang serba modern ini, masih banyak masyarakat yang menggunakan jamu cekok sebagai solusi mengatasi kesulitan makan pada anak, berat badan yang kurang, diare, batuk pilek dan masuk angin. Para ibu memberikan jamu cekok sesuai dengan kebutuhan, misalnya pada saat masuk angin diberikan dua kali sehari, pada saat diare jamu cekok diberikan dua kali sehari, diberikan satu kali sehari pada anak yang berat badannya kurang. Bahkan ada juga yang memberikan jamu hanya untuk mempertahankan berat badan dan nafsu makan pada anak, jadi anak rutin diberikan jamu seminggu sekali walaupun kondisi tubuhnya sehat dengan berat badan yang normal / sesuai dengan usianya. Hasil penelitian sebelumya, selain meningkatkan nafsu makan, jamu cekok tersebut bisa meningkatkan kesehatan, menyembuhkan beberapa penyakit ringan seperti kembung, mencret dan lain sebagainya. Kemudahan lain yang diperoleh dari ramuan jamu cekok tersebut adalah cara membuat ramuan jamu cekok tersebut mudah dilakukan, alat yang dipakai sederhana, serta bahan untuk ramuan jamu ada di pekarangan rumah, tukang sayur keliling, atau di pasar. Selain alasan diatas, penggunaan jamu tradisional karena efek samping nya sedikit atau bahkan tidak ada, sehingga digemari oleh masyarakat modern (Nugrahaningtyas, 2005).

Fenomena yang ada tersebut menarik perhatian peneliti untuk melakukan penelitian dengan tujuan untuk mengetahui khasiat ramuan jamu cekok terhadap peningkatan berat badan pada anak.

\section{Metode}

Metode penelitian yang digunakan pada penelitian ini adalah penelitian kualitatif. Sampel sumber data dalam penelitian ini adalah informan keluarga yang mempunyai anak balita yang diberi ramuan jamu cekok, penjual / pembuat ramuan jamu cekok, herbalis, dan petugas kesehatan (bidan desa dan apoteker). Pengambilan sampel dengan cara purposive sampel. Teknik pengumpulan data dilakukan melalui observasi, wawancara mendalam dan pendokumentasian. Penelitian dilakukan pada bulan Maret sampai dengan Juli 2014, di wilayah kerja Puskesmas Selogiri.

Wawancara dilakukan terhadap enam keluarga yang mempunyai anak balita yang diberikan ramuan jamu cekok sebanyak 1 ( satu ) kali dalam seminggu. Wawancara juga dilakukan pada penjual/pembuat jamu cekok, herbalis dan petugas kesehatan (bidan dan apoteker). Observasi dilakukan terhadap anak yang telah diberi ramuan jamu cekok, yang meliputi peningkatan nafsu makan dan penambahan berat badan. Persiapan, pembuatan dan cara memberikan ramuan jamu cekok juga menjadi pengamatan peneliti.

Analisis data dilakukan secara deskriptif kualitatif. Analisis data juga memanfaatkan sumber-sumber pustaka yang relevan terutama dalam bidang keperawatan anak, kesehatan, farmasi dan gizi. Pendekatan yang digunakan 
pada penelitian ini didominasi oleh pendekatan kualitatif, suatu pendekatan yang dilakukan dengan menggunakan pendekatan intensif baik perilaku maupun pendekatan secara emosional, dan bukan melakukan pendekatan yang menggunakan rumus-rumus statistik. Seluruh rangkaian dan cara kerja ataupun proses penelitian kualitatif ini berlangsung secara simultan (serentak) dilakukan dengan bentuk pengumpulan data, pengolahan data, dan menginterpretasikan sejumlah data dan fakta yang ada dan selanjutnya disimpulkan dengan metode induktif.

Uji keabsahan data yang dilakukan meliputi uji kredibilitas data (validitas internal), uji dependabilitas (reliabilitas) data, uji transferabilitas (validitas eksternal / generalisasi), dan uji konfirmabilitas (obyektivitas). Uji kredibilitas data pada penelitian ini dilakukan dengan; perpanjangan pengamatan anak dan perilaku orang tua dalam memberikan jamu cekok pada anaknya, meningkatkan ketekunan, triangulasi, diskusi dengan teman sejawat sejawat dan petugas kesehatan lain seperti bidan, promosi kesehatan, apoteker, dan herbalis, dan menggunakan bahan referensi. Triangulasi mencakup triangulasi sumber data, triangulasi teknik pengumpulan data, triangulasi waktu. Pada penelitian ini tidak ditemukan kasus negative adalah kasus yang tidak sesuai / berbeda dengan hasil penelitian hingga pada saat penelitian berlangsung. Bahan referensi yang dimaksud disini adalah pendukung untuk membuktikan data yang telah ditemukan oleh peneliti, seperti hasil rekaman suara, rekaman gambar (video) gambar/foto, sehingga bisa mendukung kredibilitas data yang telah ditemukan oleh peneliti.

Uji transferabiliti merupakan validitas eksternal dalam penelitian kualitatif. Validitas eksternal ini menunjukkan derajad ketepatan atau dapat diterapkannya hasil penelitian ke populasi dimana sampel tersebut diambil. Oleh karena itu dalam membuat laporan peneliti harus memberikan uraian dengan jelas, rinci, sistematis, dan dapat dipercaya. Uji dependaliti, dalam penelitian kualitatif, uji ini dilakukan dengan melakukan audit terhadap keseluruhan proses penelitian. Caranya dilakukan auditor yang independen, atau pembimbing untuk mengaudit seluruh aktivitas peneliti dalam melakukan penelitian. Apabila peneliti tidak mempunyai dan tidak menunjukkan jejak aktivitas lapangannya, maka dependabiliti penelitian patut diragukan. Uji konfirmabiliti hampir sama dengan uji dependabiliti sehingga pengujiannya dapat dilakukan secara bersamaan. Menguji konfirmabiliti berarti menguji hasil penelitian, dikaitkan dengan proses yang dilakukan. Bila hasil penelitian dikaitkan dengan proses yang dilakukan, maka penelitian tersebut telah memenuhi standar konfirmabiliti.

Pada penelitian ini, ada empat tahap pelaksanaan penelitian, yaitu tahap sebelum ke lapangan, tahap pekerjaan lapangan, tahap analisis data, dan tahap penulisan laporan. Pertama, tahap sebelum ke lapangan, tahap ini meliputi kegiatan penentuan fokus, penyesuaian paradigma dengan teori, penjajakan alat peneliti, mencakup observasi lapangan dan permohonan ijin kepada subyek yang diteliti, konsultasi fokus penelitian, penyusunan usulan penelitian. Kedua, tahap pekerjaan lapangan, meliputi mengumpulkan bahan-bahan yang berkaitan dengan perilaku kebiasaan memberikan jamu cekok kepada anak yang berat badannya kurang/kurang nafsu makan pada anak di wilayah Puskesmas Selogiri. Data tersebut diperoleh dengan observasi, wawancara dan dokumentasi dengan melihat bagaimana cara membuat jamu cekok, apa yang terkandung dalam ramuan jamu cekok tersebut, bagaimana cara orang tua/ penjual jamu gendong memberikan ramuan jamu cekok pada anak, apa yang dilakukan anak, bagaimana dampak setelah anak mendapat ramuan jamu cekok. Ketiga adalah tahap analisis data, meliputi analisis data baik yang diperoleh melalui observasi, wawancara mendalam maupun dokumen pada anak balita yang mendapat ramuan jamu cekok, kemudian dilakukan penafsiran data sesuai dengan konteks permasalahan yang diteliti selanjutnya melakukan pengecekan keabsahan data dengan cara mengecek sumber data yang didapat dan metode perolehan data sehingga data benarbenar valid sebagai dasar dan bahan untuk memberikan makna data yang merupakan proses penentuan dalam memahami konteks penelitian yang sedang diteliti. Keempat, 
tahap penulisan laporan, meliputi kegiatan penyusunan hasil penelitian dari semua rangkaian kegiatan pengumpulan data sampai pemberian makna data.

\section{Hasil dan Pembahasan}

Kecamatan Selogiri merupakan wilayah paling utara dari Kabupaten Wonogiri yang berbatasan langsung dengan Kabupaten Sukoharjo. Luas Wilayah: 9.325,96 Ha, wilayah administrasi: 1 desa/Kelurahan, 95 RW, dan 294 RT. Jarak: $6 \mathrm{Km}$ sebelah utara Kota Wonogiri Ketinggian: $106 \mathrm{~m}$ diatas permukaan air laut ( dpl ) Batas wilayah : sebelah utara: Kabupaten Sukoharjo, sebelah timur: Kecamatan Wonogiri sebelah selatan : Kecamatan Wonogiri, sebelah barat: Kecamatan Manyaran. Hasil pertanian padi, padi gogo, salak, buah naga. Usaha Mikro Kecil Menengah (UMKM) : industri mebel, kerajinan lukis kaca, lukisan bulu, industri makanan: jamu tradisional, ondeonde, tempe kripik Desa Kaliancar. Selain itu di wilayah kecamatan Selogiri terdapat dua perusahaan jamu tradisional berskala nasional yang mendukung kearifan lokal masyarakat Wonogiri yaitu kebisaaan minum jamu dan usaha pertanian serta UMKM yang memproduksi jamu tradisional.

Untuk mendapatkan data atau informasi yang akurat, maka dalam penelitian ini subjek penelitian adalah informan dan key informan (informan kunci). Penulis menentukan informan secara purposive, sedangkan informan kunci digunakan sebagai triangulasi sumber. Informan dalam penelitian ini adalah seorang bapak dan lima orang ibu yang anaknya rutin meminum jamu cekok. Informan kunci yang diwawancaai adalah seorang dukun bayi yang juga membuat jamu cekok, seorang apoteker herbal, dan seorang tenaga kesehatan (bidan ).

Karakteristik informan dan informan kuci dalam penelitian ini meliputi umur, jenis kelamin, pendidikan, pekerjaan, dan jumlah anak.

Berdasarkan tabel di atas dalam penelitian ini terdapat 6 informan yang berhasil diwawancarai yang termuda umur 28 tahun, sedangkan yang tertua umur 70 tahun sedangkan umur informan kunci 1 yaitu 70 tahun, informan kunci 2, 35 tahun, dan informan kunci 3 berumur 43 tahun. Dalam penelitian ini, karateristik informan dan informan kunci berdasarkan jenis kelamin terdapat 2 orang berjenis kelamin laki-laki dan 7 orang berjenis kelamin perempuan. Untuk pendidikan informan sangat variatif dari sekolah menengah pertama sampai perguruan tinggi. Dari data yang didapat pendidikan informan dan informan kunci bermacammacam. Informan 2,4,5, dan 6 pendidikan yang ditempuh tamat Sekolah Menengah Pertama, sedangkan informan 1 dan 3 mencapai tingkat perguruan tinggi. Informan kunci 1 tidak sekolah, informan kunci 2 menempuh

Tabel 1. Karakteristik informan dan informan kunci

\begin{tabular}{|c|c|c|c|c|c|}
\hline Nama & $\begin{array}{l}\text { Umur } \\
\text { (Th) }\end{array}$ & $\begin{array}{c}\text { Jenis } \\
\text { Kel }\end{array}$ & & Pekerjaan & $\begin{array}{c}\text { Jumlah } \\
\text { Anak }\end{array}$ \\
\hline Informan 1(Ibu Emi) & & $\mathrm{P}$ & D3 & Bidan & 4 \\
\hline Informan 2 (Bapak Maryanto) & & $\mathrm{L}$ & SMP & Swasta & 1 \\
\hline Informan 3(Ibu Arum) & 28 & $P$ & D3 & Guru swasta & 2 \\
\hline Informan 4 (Ibu Sri Haryanti ) & 45 & $\mathrm{P}$ & SMP & Ibu rumah tangga & 3 \\
\hline Informan 5 (Ibu Sugihartini) & 33 & $\mathrm{P}$ & SMP & Ibu rumah tangga & 1 \\
\hline Informan 6 (Ibu Rulita) & 35 & $\mathrm{P}$ & SMP & Ibu rumah tangga & 1 \\
\hline $\begin{array}{l}\text { Informan Kunci } 1 \\
\text { Pembuat Jamu (Mbah Wariyem) }\end{array}$ & 70 & $\mathrm{P}$ & $\begin{array}{l}\text { Tidak } \\
\text { sekolah }\end{array}$ & $\begin{array}{l}\text { Dukun bayi/pembuat } \\
\text { Jamu cekok }\end{array}$ & \\
\hline $\begin{array}{l}\text { Informan Kunci } 2 \\
\text { Herbalis (Bpk Kuncoro) } \\
\text { Informan kunci } 3\end{array}$ & 45 & $\mathrm{~L}$ & S1 & Herbalis & \\
\hline $\begin{array}{l}\text { Apoteker } \\
\text { (Bpk Aris) }\end{array}$ & 35 & $\mathrm{~L}$ & S1,Apt. & Apoteker & \\
\hline $\begin{array}{l}\text { Informan kunci } 4 \\
\text { Tenaga Kesehatan }\end{array}$ & 43 & $\mathrm{P}$ & $\mathrm{S} 2$ & $\begin{array}{l}\text { Bidan/Petugas } \\
\text { promkes }\end{array}$ & 2 \\
\hline
\end{tabular}


pendidikan S1 profesi Apoteker, dan informan kunci 3 menempuh pendidikan pascasarjana dengan latar belakang profesi sebagai bidan.

Berdasarkan pekerjaan informan 1 sebagai bidan desa, informan 2 sebagai pegawai swasta, informan 3 sebagai guru swasta, informan 4, 5, dan 6 sebagai ibu rumah tangga. Informan kunci 1 sebagai dukun bayi yang juga membuat jamu cekok, Informan kunci 2 bekerja sebagai apoteker di sebuah perusahaan jamu berskala nasional dan informan 3 sebagai bidan di puskesmas sekaligus sebagai petugas promosi kesehatan. Berdasarkan keterangan tabel tentang jumlah anak, jumlah anak paling banyak adalah informan kesatu dengan jumlah anak sebanyak empat, sedangkan jumlah anak yang paling sedikit adalah satu orang, dan ada juga satu informan yang mempunyai dua anak.

Cekok mengandung maksud pemaksaan. Dicekok sama dengan dicangar (dipaksa). Dicangar berarti membuka mulut dengan paksa untuk minum jamu. Pada umumnya anak yang diberi jamu cekok ini adalah anak yang menolak minum jamu / obat yang bertujuan untuk kesehatan. Menurut Informan kunci 2 bahwa jamu cekok adalah jamu tradisional yang digunakan masyarakat secara turun temurun, untuk meningkatkan nafsu makan anak. Bahan jamu cekok dapat dikategorikan sebagai jamu apabila telah digunakan oleh tiga generasi berturut turut dan menunjukkan manfaat yang positif. Menurut informan kunci 3 herbalis "Jamu cekok adalah jamu yang diberikan dengan cara dicekok (diperaskan ke mulut anak) yang umumnya bermanfaat untuk meningkatkan nafsu makan, meningkatkan sistem kekebalan tubuh, meningkatkan fungsi hati, dan lain-lain."

Menurut Informan Kunci tenaga kesehatan, jamu cekok adalah metode pemberian jamu kepada anak dengan cara diperaskan kedalam mulut anak ( dicekok), hal ini dilakukan agar anak mau minum karena biasanya anak menolak minum sebab rasanya pahit. Seperti yang diungkapkan berikut ini: “ Cekok itu metode meminumkan jamu kepada anak, dengan cara mulut anak dicangar (dipaksa dibuka) lalu jamunya diperaskan kemulut anak, sehingga anak terpaksa menelan meskipun rasanya pahit"

Menurut Informan 3, 4, 5, 6, dan informan kunci dukun bayi, jamu cekok diberikan setelah bayi lahir, sampai usia 3 tahun, karena setelah usia tersebut biasanya anak akan menggigit jari mbah dukun / pemberi jamu cekok. Menurut informan 1, jamu cekok diberikan pada usia 6 bulan, karena sebelum 6 bulan bayi hanya boleh diberi asi. Menurut informan kunci tenaga kesehatan, jamu cekok sebaiknya diberikan setelah usia 6 bulan, karena usia kurang dari 6 bulan bayi hanya boleh minum asi, mengingat fungsi pencernaan belum sempurna.

Menurut informan kunci dukun bayi bahan/empon-empon yang sering dipakai untuk membuat jamu cekok adalah kunyit, temulawak (curcuma xanthorriza robx), temu ireng (Curcuma Aereginosa), temu giring (Curcuma Heyneana), tempe bosok, lempuyang emprit (zingiber aromaticum),, dawung, daun jambu biji (Psidium Guajava L), sambiloto (andrographis paniculata ness), dan inggu. Menurut informan 4 bahan yang dipakai untuk membuat jamu cekok terdiri dari kunyit dan temulawak, temuireng, tempe bosok ( tempe yang sudah mengalami pembusukan ), lempuyang, dawung dan adas pulowaras. Selain itu jika anak cacingan ditambah dengan bunga jarak, ini sesuai pernyataan dari informan 4 Mbah dukun "Menawi mpun saged mrangkakmrangkak ngaten tho, niku kan dolanan lebu. Di cekoki temu ireng, tempe bosok, adas pulowaras, simbukan, kembang jarak, niku mateni kremi dhalem. Kersane mboten kreminen, cacingen. Yen eek rak toya sor, aruse mboten nggenah."

Pendapat dari informan 1, informan kunci 1 mbah dukun, informan kunci 2 herbalis dan informan kunci 3 apoteker, menyatakan bahwa bahan utama pembuatan jamu cekok adalah empon-empon yang terdiri dari temulawak (curcuma xanthorriza robx), lempuyang emprit (zingiber americans), temu ireng (curcuma aeruginaosa robx), daun pepaya (carica papaya l), kencur (kaempferla galanga L), kunyit (curcuma domestica val), kapulogo (amonium cardamiomum willd). Perbedaan dengan penelitian yang telah dilakukan sebelumnya oleh Limananti (2003) menyatakan bahwa bahan utama untuk membuat jamu cekok adalah sama dengan informan tersebut, hanya ada tambahan brotowali (tinospora tuberculata beume), dan tidak adanya tempe busuk pada penelitian sebelumnya. Informan kunci dukun bayi mengatakan, bahan untuk membuat jamu 
cekok tergantung dari tujuannya, misalnya untuk obat batuk ditambah dengan inggu (Ruta Angustafiola L). Menurut Informan kunci dukun bayi, tempe busuk berkhasiat untuk menghilangkan cacing kremi.

Anak yang mengalami kurang nafsu makan disebabkan oleh ketidakseimbangan produksi empedu yang berpengaruh pada dorongan makan atau rasa lapar, untuk itu perlu diberikan jamu cekok untuk merangsang produksi empedu sehingga akan terjadi peningkatan nafsu makan, dan berat badan anak bisa meningkat seiring dengan asupan nutrisi yang dikonsumsi anak. Temulawak juga memiliki efek farmakologis zat aktif sebagai anti-inflamasi (anti peradangan) dan menghambat edema (pembengkakan).

Rimpang temulawak mengandung zat kuning kurkumin, minyak atzsiri, pati, protein, lemak, Selulosa, dan mineral. Temulawak merupakan tanaman asli dari Indonesia, sejenis rempah yang bisa digunakan sebagai obat, sumber karbohidrat, bahan penyedap masakan dan minuman, pewarna alami untuk makanan dan kosmetik. Kandungan kurkuminnya berkhasiat sebagai anti tumor, antioksidan, dan obat malaria (Ramdja, et. al. 2009). Temulawak juga mengandung minyak atzsiri yang berkhasiat sebagai cholagogum, sejenis bahan yang mampu merangsang pengeluaran cairan empedu yang berfungsi sebagai penambah nafsu makan dan anti spasmodicum (menenangkan dan mengembalikan kekejangan otot. Curcuma xanthorrizae dipercaya sebagai tanaman yang mempunyai efek hepatoprotektif dan juga meningkatkan nafsu makan pada orang yang sulit makan (BKTM Makassar, 2013). Menurut Jurnal Turmeric and Curcumin : Biological Actions and Medicinal Applications menyatakan bahwa Curcuma dapat mempercepat proses pencernaan lipid oleh lipase dan meningkatkan sekresi kelenjar empedu untuk mengemulsi lemak sehingga secara tidak langsung mempercepat pengosongan lambung. Tubuh manusia memerlukan waktu lebih lama untuk mencerna lemak sehingga makanan akan lebih lama di saluran cerna, dari dasar ini maka dengan pemberian curcuma dapat proses pencernaan lemak dan pengosongan lambung, sehingga dapat meningkatkan nafsu makan anak yang kekurangan nafsu makan dan sejalan dengan hal tersebut maka asupan nutrisi akan bertambah sehingga akan menambah berat badan pada anak. Fungsi temulawak juga dapat meningkatkan nafsu makan melalui fungsinya sebagai karminativum (antiflatulen). Menurut BKTM (2013) dari beberapa penelitian yang telah dilakukan, bahwa dengan dosis 11252500 mg kurkumin perhari tidak menunjukkan adanya toksisitas. Dosis yang disarankan untuk meningkatkan nafsu makan adalah 2 gram rimpang kering temulawak, dibuat dalam bentuk infus, diminum 2-3 kali sehari. Dosis ekstrak curcuma untuk orang dewasa sebanyak 250-500 mg/hari. Dosis untuk anak-anak minimal sepertiga dari dosis orang dewasa yaitu $330 \mathrm{mg} / \mathrm{hari}$.

Informan 1 menyatakan bahwa salah satu bahan pembuat jamu cekok adalah kunyit. Kunyit mengandung antibiotik. Rimpang kunyit (Curcuma longa Linn ) mengandung zat warna kurkuminoid, yang bermanfaat menambah nafsu makan, yang merupakan suatu senyawa dari diarilheptanoid 3-4\% yang terdiri dari curcumin, dihidrocurcumin, desmetoksikurmin, dan bisdesmetoksikurmin. Sedangkan menurut Hartono dkk (2005), menyatakan bahwa kunyit mengandung senyawa curcumin yang bermanfaat terhadap hepatoprotektor terhadap kerusakan hepar hewan uji akibat pemberian asetaminofen yang ditandai dengan kenaikan kadar SGOT dan SGPT.

Pernyataan informan kunci (Apoteker) salah satu bahan jamu cekok adalah meniran. Meniran (Phyllanthus niruri) merupakan sejenis tanaman obat yang berfungsi sebagai immunomodulator (sistem imun/kekebalan tubuh). Sistem imun/kekebalan tubuh adalah suatu mekanisme pertahanan tubuh yang bertugas merespon/menanggapi "serangan" dari luar tubuh. Apabila sistem imunitas seseorang optimal, maka dia tidak mudah terserang penyakit. Senyawa yang berperan meningkatkan aktivitas sistem imun berasal dari golongan flavonoid, kurkumin, limonoid, vitamin $\mathrm{C}$, vitamin $\mathrm{E}$ (Tokoferol) dan katekin. Menurut Mathur (2011), menyatakan bahwa ekstrak meniran (Phyllanthus niruri) memiliki aktivitas melindungi hati dari zat toksik baik berupa parasit, obat-obatan, virus maupun bakteri. Penelitian lain yang mendukung 
penelitian ini adalah penelitian yang telah dilakukan oleh Kashaw (2011), yang menyatakan ekstrak meniran (Phyllanthus niruri) memiliki aktivitas melindungi sel hepatosit hati dari karbon tetraklorida dan sitotoksitas yang diinduksi dengan galaktosamin. Penelitian yang telah dilakukan Aminul (2008), menyatakan bahwa tumbuhan meniran (Phyllanthus Amarus) mempunyai aktivitas sebagai antitumor pada dosis $50 \mathrm{mg} / \mathrm{kg}$ dan $100 \mathrm{mg} / \mathrm{kg}$. Sedangkan menurut Muruguaiyah and Chan (2009), menyatakan bahwa Phyllanthus niruri linn bisa digunakan untuk mengobati asam urat (berfungsi sebagai efek antihyperuricemic). Narendra (2012), juga telah melakukan reviev dari beberapa penelitian bahwa Phyllanthus niruri memiliki molekul bioaktif seperti lignan, phyllanthin, flavonoid, glikosida, tanin, alkaloid, ellagitannins, propanoid, steroid, asam ricinolic, niruriside dan phyltetralin. Tanaman ini digunakan sebagai obat tradisional untuk mengobati penyakit batu ginjal, batu kandung empedu, penyakit hati, selain itu juga berfungsi sebagai diuretik, antiinflamasi, antitumor, dan anti oksidan.

Pernyataan dari informan kunci yang menyatakan kencur bisa menjadi obat batuk, mengeluarkan lendir adalah sesuai dengan penelitian yang dilakukan oleh Hasanah (2011), yang menyatakan tentang khasiat yang terkandung dalam kencur yaitu sebagai obat antiinflamasi.

Pernyataan tersebut diperkuat oleh penelitian yang telah dilakukan oleh Sulaiman (2007) bahwa rimpang kencur dapat digunakan sebagai obat hipertensi, rematik, asma, dan antiinflamasi.

Menurut informan 4 dan informan kunci mbah dukun, salah satu bahan utama pembuatan jamu cekok adalah lempuyang. Lempuyang emprit (Zingiber Americans B1) merupakan tanaman obat yang banyak dipakai oleh masyarakat sebagai penambah nafsu makan, mengobati sakit perut, mencret, badan penat, asma, dan mencegah kehamilan (Karima, 2007). Lempuyang emprit bisa menyembuhkan sakit perut dan diare karena kandungan minyak atsiri yang terdapat dalam lempuyang memiliki sifat bakteriostatik dan bakteristik terhadap E.Coli. selain minyak atsiri, kandungan senyawa yang terdapat dalam lempuyang emprit adalah saponin, dan flavonoid. Golongan senyawa saponin berkhasiat mencegah kanker, flavonoid bersifat antioksidan. E. Coli merupakan bakteri yang menyebabkan infeksi saluran cerna yang bisa menyebabkan nafsu makan menurun dan sakit perut, sehinga dengan pemberian lempuyang emprit ini diharapkan menghambat pertumbuhan bakteri E. Coli sehingga tidak mengganggu organ-organ pencernaan, meningkatkan nafsu makan dan menambah berat badan pada anak.

Menurut informan 4 dan informan kunci 1 menyatakan bahwa adas pulowaras merupakan bahan jamu cekok Adas Pulowaras merupakan tanaman obat yang bisa digunakan untuk membuat ramuan jamu cekok yang bisa membuat bayi sehat. Menurut Hasanah (2004), adas (Foeniculum Vukgare Mill) merupakan merupakan salah satu jenis tanaman yang digunakan sebagai bahan baku obat, jamu, bumbu masak serta untuk menanggulangi masalah kurang tidur. Tidak hanya di Indonesia, adas ternyata juga banyak digunakan sebagai obat di beberapa negara seperti Cina, Meksiko, dan India. Penyakit yang bisa disembuhkan dengan adas ini adalah penyakit dada, ginjal, punggung, perut kejang, kanker usus dan gangguan pernapasan (Charles dalam Hasanah 2004).

Informan 4 dan Informan kunci 1 menyatakan bahwa temu ireng merupakan bahan utama pembuat jamu cekok, seperti pernyataan informan 4 berikut ini " "Kulo ngangge temu ireng kersane nafsu makan e sae", sedangkan informan kunci 1 menyatakan pemberian temu ireng agak tidak cacingan, seperti yang diungkapkan berikut ini " Menawi mpun saged mrangkak-mrangkak ngaten tho, niku kan dolanan lebu. Di cekoki Temu ireng, ..... niku mateni kremi dhalem. Kersane mboten kreminen, cacingen". Menurut Nugrahaningtyas (2005), tanaman temu ireng (Curcuma aeruginosa Roxb) dari famili Zingiberaceae merupakan salah satu dari sekian banyak tanaman obat tradisional yang ada di Indonesia. Tumbuhan ini mengandung saponin, flavonoid, dan polifenol, disamping minyak atsiri. Flavonoid yang terdapat dalam temu ireng ini masuk dalam golongan isoflavon. Isoflavon merupakan antioksidan alami yang bisa menurunkan risiko penyakit kanker, 
mempercepat proses penyembuhan penyakit dan menurunkan kadar kolesterol sehingga bisa mencegah terjadinya penyakit jantung.

Menurut informan 4 dan informan

kunci 1, salah satu bahan pembuatan jamu cekok adalah tempe bosok (tempe yang telah busuk). Tempe merupakan makanan yang sangat populer di Indonesia. Selain harganya yang murah, mudah didapat, ternyata tempe banyak mengandung gizi yang bisa disejajarkan dengan daging. Dibanding dengan kedelai, tempe lebih banyak mengandung gizi, disebabkan oleh kapang yang tumbuh pada tempe dapat menghidrolisis sebagian selulosa menjadi bentuk yang lebih mudah dicerna oleh tubuh manusia. Para peneliti menganggap bahwa jamur yang paling aktif dalam tempe yaitu rhizopus sp. Jamur tersebut menghasilkan enzim-enzim yang mampu merombak senyawa organik kompleks menjadi senyawa yang lebih sederhana, sehingga lebih cepat digunakan oleh tubuh. Bukti empiris pada bayi dan anak balita penderita gizi buruk dan diare kronik. Sepotong tempe mengandung karbohidrat, lemak, protein, serat, vitamin, enzim, serta komponen anti bakteri yang sangat bermanfaat untuk kesehatan. Jenis vitamin yang terdapat dalam tempe antara lain vitamin B1 (thiamin), B2 (riboflavin), piridoksin, niasin, asam folat, biotin dan asam pantotenat. Vitamin B12 terjadi peningkatan paling tinggi yaitu 33 kali selama fermentasi. Vitamin ini diproduksi oleh bakteri kontaminasi seperti klebsiella pneumoniae dan citrobacter freundi. Vitamin ini sangat penting dalam pembentukan sel darah merah, sehingga bisa mencegah terjadinya anemia (Deliani, 2008). Tempe juga mengandung isoflavon, yang berperan sebagai antioksidan untuk menghentikan reaksi pembentukan radikal bebas. Pembentukan antioksidan ini disintesis pada saat terjadinya fermentasi kedelai menjadi tempe oleh bakteri micrococcus leteus dan coreyne bacterium (Paimin, F.R dalam Deliani, 2008). Menurut Deliani (2008) sebaiknya tempe dikonsumsi sebelum fermentasi 50 jam, karena kadar protein lemak tertinggi pada waktu tersebut. Namun, fermentasi setelah 72 jam sampai 96 jam, kadar asam sitat rendah karena sudah dihidrolisis total, maka penyerapan utama tidak terhalang lagi sehingga mutu gizinya bertambah baik. Dari penjelasan diatas bisa ditarik kesimpulan, bahwa penggunaan tempe busuk pada ramuan jamu cekok sebaiknya setelah tempe difermentasi setelah 24 jam dan sebelum 96 jam.

Informan kunci 1 mengatakan bahwa pembuatan jamu cekok tergantung dari kebutuhan, misalnya anak yang batuk ramuan yang sudah ada ditambah dengan inggu. Pernyataan informan 1 tersebut sesuali dengan penelitian yang telah dilkaukan oleh Yenisbar (2013) bahwa inggu merupakan tanaman obat yang banyak sekali manfaatnya. Daun Inggu (Ruta Angustafiola L) dapat digunakan untuk mengobati beberapa macam penyakit, seperti demam, influenza, batuk, radang paru, kejang pada anak, dan cacingan (Dalimarta dalam Yenisbar, 2013), untuk obat batuk gunakan daun inggu sebanyak 2-4 gram daun inggu direbus dengan air 2-3 gelas, setelah airnya setengahnya, airnya disaring dan diminum. Air rebusan daun inggu juga bisa digunakan sebagai obat penenang pada anak yang kejang dengan cara dikompreskan diusapkan keseluruh tubuh / cuci muka. Selain itu, cara lain untuk mengatasi kejang pada anak yaitu dengan menggunakan daun inggu segenggam ditumbuk bersama dengan 1 siung bawang merah setelah rata tempelkan diubun - ubun anak.

\section{Penutup}

Ramuan jamu cekok telah terbukti secara empiris meningkatkan nafsu makan dan berat badan. Jenis ramuan jamu cekok yang berkhasiat untuk meningkatkan berat badan adalah kunyit, temulawak (curcuma xanthorriza robx), temu ireng (Curcuma Aereginosa), temu giring (Curcuma Heyneana), lempuyang emprit (zingiber aromaticum), papaya (carica papaya l), sambiloto (andrographis paniculata ness) tempe bosok (tempe yang sudah difermentasi 24 sampai 96 jam). Dari beberapa penelitian yang telah dilakukan, bahwa dengan dosis 1125-2500 mg kurkumin perhari tidak menunjukkan adanya toksisitas. Dosis yang disarankan untuk meningkatkan nafsu makan adalah 2 gram rimpang kering temulawak, dibuat dalam bentuk infus, diminum 2-3 kali sehari. Dosis ekstrak curcuma untuk orang dewasa sebanyak 250-500 mg/hari. Dosis untuk anak-anak minimal sepertiga dari dosis orang 
dewasa yaitu $330 \mathrm{mg} /$ hari.

\section{Ucapan Terima Kasih}

Penulis mengucapkan terimakasih kepada Tutor Penulisan Artikel Ilmiah yang telah memberikan bimbingannya dalam penulisan artikel ini. Selain itu tak lupa penulis mengucapkan terimakasih kepada Ketua LPPM dan Direktur Akper Giri Satria Husada Wonogiri yang telah memberikan bantuan baik secara langsung maupun tidak langsung kepada kami. Dan Kepada Ditlitabmas Dikti, terimakasih atas bantuan dana yang diberikan untuk mengadakan penelitian ini.

\section{Daftar Pustaka}

Atun, S., dkk. 2010. Efek Sitotoksik Ekstrak Umbi Tumbuhan Temu Giring (Curcuma Heyneana) dan Temu Ireng (Curcuma Aeruginosa) Terhadap Beberapa Sel Kanker. Jurnal Penelitian Santek, 15 (2).

Balai Kesehatan Tradisional Masyarakat Makassar. 2013. Pengaruh Pemberian Temulawak (Curcuma xanthorriza Roxb) terhadap Kenaikan Berat Badan pada Anak Usia Sekolah. Makassar.

Deliani. 2008. Pengaruh Lama Fermentasi Terhadap Kadar Protein, Lemak, Komposisi Asam Lemak Dan Asam Fitat Pada Pembuatan Tempe. Tesis. Medan. Pascasarjana USU.

Dewi. R.K., Budiantara. I.N., 2012, Faktor - Faktor yang Mempengaruhi Angka Gizi Buruk di Jawa Timur dengan Pendekatan Regresi Non Parametrik Spline. Jurnal Sains dan Seni ITS 1.

Hasanah, A.N., dkk. 2011. Analisis Kandungan Minyak Atsiri dan Uji Aktivitas Antiinflamasi Ekstrak Rimpang Kencur (Kaempferia galanga L.). Jurnal Matematika \& Sains, 16 (3) : 147-152.

Hasanah, M. 2004. Perkembangan Teknologi Budi Daya Adas (Foeniculum Vulgare Mill). Jurnal Litbang Pertanian, 23(4).

Hartono. dkk. 2005. Pengaruh Ekstrak Rimpang Kunyit (Curcuma Domestica Val.) terhadap Peningkatan Kadar SGOT dan SGPT Tikus Putih (Rattus Norvegicus) akibat Pemberian Asetaminofen. Biofarmasi 3 (2): 57-60.

Haryudin, W., Rostiana, O. 2008. Karakteristik Morfologi Bunga Kencur (Kaempferia galanga L). Balai Penelitian Tanaman Obat dan Aromatik. Bul. Littro. 19 (2): 109-116.

Karima, N. 2007. Profil Kromatogram Dan Aktivitas Antibakteri Ekstrak Etanol Rimpang
Lempuyang Emprit (Zingiber American B1). Terhadap Bakteri Escherichia Coli In Vitro. Skripsi. Semarang. Fakultas Kedokteran UNDIP.

Kashaw, V. Nemal, et al. 2011. Hepatoprotective Prospective Of Herbal Drugs and Their Vesicular Carriers-A. Review. International Journal of Research in Pharmaceutical and Biomedical Sciences 2: 1-15. India.

Limananti \& Triratnawati. 2003. Ramuan Jamu Cekok sebagai peneyembuhan kurang nafsu makan pada anak: suatu kajian etnomedisin. Makara. Kesehatan. Vol. 1.

Mathur, R. 2011. Antimicrobial Effect of Phyllanthus niruri on Human Pathogenic Microorganisms. International Journal of Drug Discovery and Herbal Research 1(4) : 234-238.

Murugaiyah. V., Chan. K. 2009. Mechanisms of Antihyperuicemic Effect of Phyllanthus niruri and Lignan Constituents. Journal of Ethnopharmacology, 124(2):233-9. Doi: 10.1016. Universitas Sains Malaysia.

Nugrahaningtyas, K.D., Matsjeh, S., Wahyuni, T.D. 2005. Isolasi dan Identifikasi Senyawa Flavonoid dalam Rimpang Temu Ireng (Curcuma aeruginosa Roxb). Biofarmasi, 3 (1): 32-38.

Rahim. F.K., 2014, Faktor Risiko Underweight Balita Umur 7 - 59 Bulan, Jurnal Kemas 9 (2) 115 $-121$.

Ramdja, A.F., Aulia, R.M.A., Mulya, P. 2009. Ekstraksi Kurkumin dari Temulawak dengan Menggunakan Etanol. Jurnal Teknik Kimia, 3 (16).

Setyowati. M., Astuti. R., 2015, Pemetaan Status Gizi Balita dalam mendukung Keberhasilan Pencapaian Millenium Development Goals (MDG's), Jurnal Kemas 10 (2) $110-121$.

Sulaiman, M. R. Z. A., dkk. 2007. Antinociceptive and Anti-inflammatory Activities of the Aqueous Extract of Kaempferia galanga Leaves in Animal Models. J. Nat. Med, 62 : 221-227.

Suryanto, Purwandari. H., Mulyono. W.A., 2014, Dukungan Keluarga dan Sosial dalam Pertumbuhan dan Perkembangan Personal Sosial, Bahasa dan Motorik pada Balita di Kabupaten Banyumas, Jurnal Kemas 10 (1) : 103 - 109.

Yenisbar, Yarni, Amelia, 2013. Multiplikasi Tunas Tanaman Inggu (Ruta Angustifolia L.) Secara Invitro Dengan Penambahan Benzyl Adenin. E-Journal WIDYA Kesehatan dan Lingkungan 1 (1). Universitas Nasional. 